\title{
Impact of an Organic Acid and Calcium Chloride Solution on Minimally Processed Breadfruit Quality
}

\author{
Angélica de Kássia Barbosa Flôr ${ }^{1}$, Thaís Regina Rodrigues Vieira ${ }^{1}$, \\ Edleide Freitas Pires $^{2}$, Daniele $S$ Ribeiro ${ }^{1}$ and Maria Inês Sucupira \\ Maciel $^{1 *}$ \\ ${ }^{1}$ Food science and technology Graduation Program, Federal Rural University of \\ Pernambuco, Brazil \\ ${ }^{2}$ Rural Technology Department, Federal Rural University of Pernambuco, Brazil \\ *Corresponding Author: Maria Inês Sucupira Maciel, Food science and technology \\ Graduation Program, Federal Rural University of Pernambuco, Brazil.
}

DOI: $10.31080 /$ ASNH.2022.06.1013

\begin{abstract}
Breadfruit (Artocarpus altilis) is described as an important food source in the diet of several countries and it is considered a valuable food resource with the potential to positively affect food security in the world. The aim of this study was to evaluate the impact of an organic acid and calcium chloride solution on the physicochemical characteristics of fresh-cut breadfruit. Breadfruit was processed and two groups were separated with and without immersion treatment in a solution containing $2 \%$ citric acid, $0.2 \%$ ascorbic acid, and $5 \%$ calcium chloride. Samples were drained and stored at $6^{\circ} \mathrm{C} \pm 1{ }^{\circ} \mathrm{C}$ for 15 days. Chemical composition, physical characteristics, bioactive compounds, antioxidant activity, and microbial behavior were determined every two days. The direct relationship between total phenolic content and the antioxidant capacity of the analyzed samples was observed. Treated samples had higher total phenolic content statistically significant, $(\mathrm{p}<0.05)$, when compared with control samples during the storage time 0 $=350.65 \pm 1.89 ; 3$ days $=250.61 \pm 1.75 ; 5$ days $=240.11 \pm 2.03 ; 7$ days $=150.69 \pm 2.68 ; 10$ days $=280.40 \pm 1.43 ; 13$ days $=240.87 \pm$ $1.46 ; 15$ days $=350.60 \pm 1.64 \mathrm{mg} \mathrm{GAE} .100 \mathrm{~g}-1$ dry sample. And higher antioxidant activity, $(\mathrm{p}<0.05)$, compared with control samples, for both DPPH. time $0=69.34 \pm 0.05 ; 3$ days $=50.69 \pm 0.07 ; 5$ days $=46.31 \pm 0.09 ; 7$ days $=200.36 \pm 0.04 ; 10$ days $=83.05 \pm 0.06 ; 13$ days $=59.70 \pm 0.07 ; 15$ days $=33.33 \pm 0.04 \mathrm{EC} 50 \mathrm{in} \mu \mathrm{g} / \mathrm{mL}$ and ABTS + radicals, at time $0=53.98 \pm 0.04 ; 3$ days $=54.57 \pm 0.05 ; 5$ days $=92.30 \pm 0.20 ; 7$ days $=58.59 \pm 0.10 ; 10$ days $=82.54 \pm 0.03 ; 13$ days $=78.32 \pm 0.09 ; 15$ days $=188.60 \pm 0.06 \mu$ mol Trolox $/ \mathrm{g}$ sample . It was concluded that the used solution improved the physicochemical characteristics of the fruit, by increasing its phenolic content and antioxidant activity.
\end{abstract}

Keywords: Antioxidant Capacity; Lifespan; Bioactive Compounds; Wild Plant

\section{Abbreviations}

ABTS: Ability to Sequester Radical 2,2'-Azinobis (3-Ethylbenzothiazoline-6-Sulfonic Acid); AC: Citric Acid; $\mathrm{a}_{\mathrm{w}}$ : Water activity; B: Mold; CT: Total Coliforms; CTM: Total Mesophyll Count; DI: Darkening Index; DPPH: Ability to Sequester Radical 2,2-Diphenyl-1-Picrylhydrazyl; EC: Escherichia Coli; L: Yeast; NDF: Neutral Detergent Solution; pH: Hydrogen Potential; PPO: Polyphenol Oxidase; RH: Relative Humidity; SS: Soluble Solids; TEAC: Total Antioxidant Capacity Equivalent to Trolox; WI: Whiteness Index

\section{Introduction}

Breadfruit has a long and historic history of cultivation and use. In recent years, there has been a growing interest in promoting breadfruit as a nutritious and income-generating food. From a nutritional point of view, breadfruit is rich in carbohydrates, minerals, vitamins and low in fat. It is a good source of fiber, calcium, copper, iron, magnesium, potassium, thiamine and niacin; some varieties are good sources of antioxidants and carotenoids. According to the National Tropical Botanical Garden, more than $80 \%$ of the population that does not have a guarantee of nutritional security lives 
in tropical and subtropical regions, being the perfect environment for the cultivation of breadfruit. This fruit could become the next "superfood" capable of alleviating hunger and ensuring nutrition for the population. In 2016, a breadfruit flour received the status of 'Generally recognized as safe', thus opening up the possibility of using this flour as an ingredient in different foods [1-3].

The term "minimal processing" refers to the use of one or more methods, techniques, or procedures to transform either plant or animal-derived foods into ready-to-eat products while maintaining the original nutritional and organoleptic qualities. As the world is increasingly interconnected through globalization, it has become a priority to expand the market as much as possible. Consumption of minimally processed fruits and vegetables has become increasingly popular over the last decade due to a greater interest in healthy and nutritious diets and changes in consumer lifestyle. The successful application of minimal processing delays nutrient loss and undesirable changes in texture, color, flavor, and aroma related to ripening or microbial spoilage [4]. In the case of fruits and vegetables, one of the main and persistent problems faced by the food industry for minimal processing is related to perishability, rapid deterioration, and loss of quality attributes. These products have higher perishability and susceptibility to deterioration than raw fruits or vegetables because mechanical injuries to plant tissue promote physiological changes, microbiological spoilage, and a loss of overall quality attributes $[4,5]$.

Many studies suggest that treatment with additives along with other techniques such as modified atmosphere packaging, and dielectric barrier discharge cold plasma treatment, $\gamma$-irradiation, non-thermal plasma treatments, edible films, and other emerging technologies can reduce oxidative stress and consequently the restriction on dimming; as well as the increase of the firmness and also the extension of product lifespan [6-10].

In order to study northeastern breadfruit, especially from Pernambuco state orchards, this study had the objective to evaluate physicochemical characteristics of minimally processed breadfruit, with the addition of a conservative solution, aiming the increase its lifespan and, consequently, provide greater profitability to producers.

\section{Materials and Methods}

Materials

Twenty kilograms of breadfruit selected according to maturation stage "swollen (between green and ripe)", skin color dark green, and size at the average of $1615 \mathrm{~g}$ were washed and sanitized in dehydrated sodium dichloroisocyanurate solution for 15 minutes. They were, then, peeled and cut manually with stainless steel knives and immediately placed underwater at $7^{\circ} \mathrm{C} \pm 0.5^{\circ} \mathrm{C}$.

\section{Methods}

Sample preparation for analysis

For the analysis, after selection, twelve kilos of peeled breadfruit were cut in half-moon format $(15 \times 5 \times 5 \mathrm{~cm})$ and washed with water, drained, and divided into two groups. Control (six kilograms were packed in trays of expanded polystyrene, covered with a film of polyvinyl polychloride ( $20 \mu \mathrm{m}$ thick, containing $200 \mathrm{~g}$ each) and with treatment (six kilograms submitted to immersion in a solution containing $2 \%$ citric acid, $0.2 \%$ ascorbic acid and $5 \%$ calcium chloride for 5 minutes at room temperature $\left(25^{\circ} \mathrm{C} \pm 2{ }^{\circ} \mathrm{C}\right)$. They were then, drained and packaged in the same manner as the control sample. Samples were stored for 15 days at $6^{\circ} \mathrm{C} \pm 1^{\circ} \mathrm{C}$ and relative humidity $(\mathrm{RH})$ of $82-90 \%$.

\section{Physico-chemical parameters}

The analyzes were performed in triplicate according to the following procedures:

- Soluble solids: Expressed in ${ }^{\circ}$ Brix and determined at $25^{\circ} \mathrm{C}$ using a Reichert digital bench refractometer (Model r2i300, São Paulo, Brazil).

- $\quad \mathbf{p H}$ : Expressed in pH unit, determined by direct immersion of the electrode of the pH-meter Tec-3 MP (Technal brand, São Paulo, Brazil) in the comminuted and homogenized pulp with value automatic correction by the temperature.

- Water Activity: Determined in water activity analyzer (Aqualab brand, Series 4TE, Washington, EUA) at $25^{\circ} \mathrm{C}$.

- Titratable acidity: Titratable acidity was determined by titration with $0.1 \mathrm{~N} \mathrm{NaOH}$ until pH 8.1 was reached (AOAC Official Method, 920.15) [11], and expressed as mg citric acid.100g-1 on a fresh weight basis.

- Pulp firmness: In order to indicate the consistency of the pulp penetration, some tests were performed in 3 points, using a suitable analog penetrometer for fruits (Facchini brand Srl, model FT 327, Italy).

\section{Color measurement}

The surface color of breadfruit was determined in the CIE $\mathrm{L}^{*} \mathrm{a}^{*} \mathrm{~b}^{*}$ system, using Konica Minolta portable colorimeter (Model CR/400/410 - Sensing, INC, Japan) calibrated with a white porcelain plate. Approximately $2 \mathrm{~g}$ of sample was placed in a plastic base of $2 \mathrm{~mm}$ of thickness. For each sample, an average value of analy- 
sis of the extremities and the center of the sample was collected in triplicate. CIE $\mathrm{L}^{*} \mathrm{a}^{*} \mathrm{~b}^{*}, \mathrm{~L}^{*}$ system represents the brightness $\left(\mathrm{L}^{*}=\right.$ 0 is black and $L^{*}=100$ white). The parameters that indicate color direction are: $+\mathrm{a}^{*}=$ red and $-\mathrm{a}^{*}=$ green; $+\mathrm{b}^{*}=$ yellow and $-\mathrm{b}^{*}=$ blue [12].

Whiteness index (WI) and darkening index (DI) were calculated according to the following Equation 1 [13].

$\mathrm{IB}=\mathrm{L}^{*}-3 \mathrm{~b}^{*}$

$\mathrm{IE}=[100(\mathrm{x}-0.31)] / 0.172$. Where $\mathrm{x}=\left(\mathrm{a}^{*}+1.75 \mathrm{~L}^{*}\right) /\left(5.645 \mathrm{~L}^{*}+\right.$ $\mathrm{a}^{*}-3.012 \mathrm{~b}^{*}$ [ [Equation 1]

\section{Mass Loss Determination}

Mass loss during storage of minimally processed (control and treated) breadfruit was carried out using an electronic analytical scale (Mark JK-EAB, model 2204N, China) with an accuracy of \pm $0.0001 \mathrm{~g}$. Mass loss was calculated by the following Equation 2.

Mass loss $(\%)=(\mathrm{mt}-\mathrm{mc}) \times 100 / \mathrm{mc}$. Where $\mathrm{mc}$ is the initial weight of minimally processed breadfruit and $\mathrm{mt}$ is the final sample weight at time t. [Equation 2]

\section{Chemical composition}

Moisture - Determined in infrared humidity meter with coupled scale (Model ID 50, brand Marte ${ }^{\circledR}$ ) at $105^{\circ} \mathrm{C}$ for $30 \mathrm{~min}$ by weight difference, before and after drying, up to constant weight and expressed in g.100g-1 of fruit.

Fixed Mineral Residue (Ashes) - Determined by gravimetry in a muffle kiln microprocessor (Model Edgcon 1P, brand EDG, São Paulo) at $550-570^{\circ} \mathrm{C}$ until constant weight, according to AOAC: Official Method 940.26 [11] and results expressed in g.100g-1 of fruit.

Lipids (Ethereal Extract) - Ethereal extract fraction was determined in an intermittent Soxhlet extractor, using Ethyl Ether P.A. as solvent. After solvent extraction and removal, the number of lipids present in the sample (AOAC Official Method, 920.39 C) [11] was gravimetrically determined. The results were expressed in g.100g-1 of fruit.

Proteins - Determined by Kjeldahl method, based on organic matter destruction followed by distillation, nitrogen being measured by volumetry. Nitrogen present in the resulting acid solution was determined by steam distillation followed by titration with dilute acid. The percentage of sample protein fraction is calculated using factor 6.25 , considering for each $100 \mathrm{~g}$ of protein, on average, 16g of nitrogen, according to AOAC Official Method 960.52 [11]. They were expressed in g.100-1 of fruit.

Total Sugars - It was determined by the Lane-Eynon method. It is based on the ability of glycids, in a strongly hot alkaline medium, to form enodiol, a compound with strong reducing power, which in the presence of $\mathrm{Cu}++$ oxidizes and reduces copper to $\mathrm{Cu}+$, giving rise to a red brick precipitate of $\mathrm{Cu} 20$, according to methodology recommended by AOAC Official Method 991.43 [11]. The results were expressed in g.100-1 of fruit.

Carbohydrates - Carbohydrate content was calculated by the difference between 100 and the sum of percentages of water, protein, total lipids, and ashes and expressed in g.100-1 of fruit.

Fibers - It was determined by the method proposed by Van Söest [14], using neutral detergent solution (NDF), which solubilizes all plant material, except for the wall structure, which are insoluble fibers (cellulose, hemicellulose, and lignin). This method quantifies the insoluble fraction of fiber. The results were expressed in g.100-1 of fruit.

\section{Total phenolics}

Breadfruit Extract - It was obtained using distilled water to result in an aqueous extract. $25 \mathrm{~g}$ of breadfruit pulp and $25 \mathrm{ml}$ of distilled water of $1: 1(\mathrm{~m}: \mathrm{v})$ were used to prepare the extracts. The mixture was homogenized for 1 hour in Erlenmeyer flasks, using a magnetic stirrer; then it was centrifuged at $6,000 \mathrm{rpm}$ for $10 \mathrm{~min}$ utes. The supernatant was stored in amber glass under refrigeration at $8^{\circ} \mathrm{C}$ until analyses.

Determination of total phenolic - the content of total phenolic compounds was determined according to the Folin-Ciocalteau method [15]. To the extract $(100 \mu \mathrm{L}), 3.9 \mathrm{~mL}$ of water was added, followed by the addition of $250 \mu \mathrm{L}$ of Folin-Ciocalteau reagent and $750 \mu \mathrm{L}$ of sodium carbonate solution. The mixture was maintained in a homogenizer (Certomat ${ }^{\circledR} \mathrm{MV}$, B. Braun Biotech International) and then incubated for $1 \mathrm{~h}$ at room temperature $\left(22 \pm 2^{\circ} \mathrm{C}\right)$ in the absence of light. The absorbance of the mixture was measured at $765 \mathrm{~nm}$ by spectrophotometry (Hitachi U-2800 Spectrophotometer, Japan). Total phenol content was determined from the calibration curve, prepared with the gallic acid standard solution, and expressed as mass of gallic acid equivalents per fresh fruit mass. The results were expressed in mg of total phenolics in gallic acid equivalents $/ 100 \mathrm{~g}$ of the sample. 
Antioxidant capacity evaluation

Ability to sequester radical 1.1-diphenyl-2-picrylhydrazyl DPPH - It was determined according to the method described by BrandWilliams, Cuvelier, and Berset [16], modified by Sanchez-Moreno, Larrauri, Saura-Calixto [17]. In this method, DPPH. reduction by the antioxidant compound results in loss of absorbance and the degree of discoloration of the solution indicates the efficacy of the tested compound. Different concentrations of breadfruit extracts were added to DPPH. solution in methanol ( $0.1 \mathrm{M})$, in order to reach final concentrations of $7.5 ; 15$ and $30 \mu \mathrm{g}$ of phenolic of the extract. Absorbance at $517 \mathrm{~nm}$ was recorded in a spectrophotometer (Shimadzu Europa UV-1650PC) until the reaction reaches the plateau. The ability to sequester DPPH. radical was expressed as a percentage; calculated in relation to the control (without the addition of antioxidant). Using the Equation 3. The absorbance of control to express in EC50 plot the \% inhibition x phenolic concentration of extract. Line equation was plotted using line equation EC 50.

$\%$ inhibition $=$ Absorbance of control - Absorbance of sample x100/ Absorbance of control. [Equation 3]

Ability to sequester radical ABTS ${ }^{+}$- Ability to sequester 2.2'-azino-bis (3-ethylbenzothiazoline-6-sulfonic acid (ABTS. +) radical was determined according to the method described by Re., et al. [18]. ABTS. + radical was generated from its aqueous solution reaction with $(7 \mathrm{mM})$ with $2.45 \mathrm{mM}$ of potassium persulfate. A radical solution was diluted in ethanol until the absorbance measurement was $0.7 \pm 0.005$, at wavelength $734 \mathrm{~nm}$. Several concentrations of breadfruit extracts diluted in ethanol were added to ABTS. + solution, reaching the final concentrations of $0.5 ; 1$ and $2 \mu \mathrm{g}$ phenolic of the extract. Absorbance was recorded after 6 minutes of reaction in a spectrophotometer (Shimadzu Europa UV-1650PC). Sample antioxidant capacity was calculated in relation to synthetic antioxidant Trolox activity (6-hydroxy-2.5.7.8-tetramethylchromo-2-carboxylic acid) under the same conditions and the results were expressed in an antioxidant activity equivalent to Trolox $\mu$ mol TEAC.g-1).

\section{Microbiological analysis}

Microbiological analyzes were performed according to $\mathrm{Wu}$ and Chen method [19], with modifications. From each sample, a $25 \mathrm{~g}$ portion was used, which was diluted in $225 \mathrm{ml}$ of $0.1 \%$ of peptone water in a sterile bag. The diluted sample was manually macerated and homogenized. From each dilution, successive dilutions were prepared, up to 10 - 4. From each dilution, $1 \mathrm{~mL}$ portions were inoc- ulated for 3 types of PetrifilmTM plates: EC (Official AOAC Method 991.14 and 998.08) [11] to determine coliforms and Escherichia coli, YM for yeasts and molds (Official AOAC Method 997.02) [11], and AC for Total Mesophil Count (AOAC Official Method 990.12) [11]. AC and EC plates were incubated at $35^{\circ} \mathrm{C} \pm 1^{\circ} \mathrm{C} / 24 \mathrm{~h}-48 \mathrm{~h}$ and YM plates at $25^{\circ} \mathrm{C} \pm 1^{\circ} \mathrm{C} /$ up to 120 hours. Results were expressed as a log of colony-forming units per gram of sample (log UFC/g).

\section{Statistical analysis}

All determinations were performed in triplicate and data were computed and submitted to variance-ANOVA analysis. The averages of obtained values were submitted to Student's t-test and Tukey's test, using the statistical program "Statistica" (version 7, StatSoft, Inc, Tulsa, USA). Significance level of 5\% probability ( $\mathrm{p}<$ 0.05 ) was set.

\section{Results and Discussion}

Physicochemical characteristics of minimally processed breadfruit

Factors influencing the quality of minimally processed fruits result in a series of biochemical and physical-chemical modifications, which mainly affect the taste, color, and texture [4]. It is known that $\mathrm{pH}$ influences the rate of various chemical, enzymatic and microbiological reactions. Variations of this parameter indicate important changes in fruit quality. The $\mathrm{pH}$ found in the studied sample (Figure 1) was higher than that reported by Roopa., et al. [20] when evaluating the lifespan of minimally processed breadfruit, packaged under a passive modified atmosphere and stored under refrigeration.

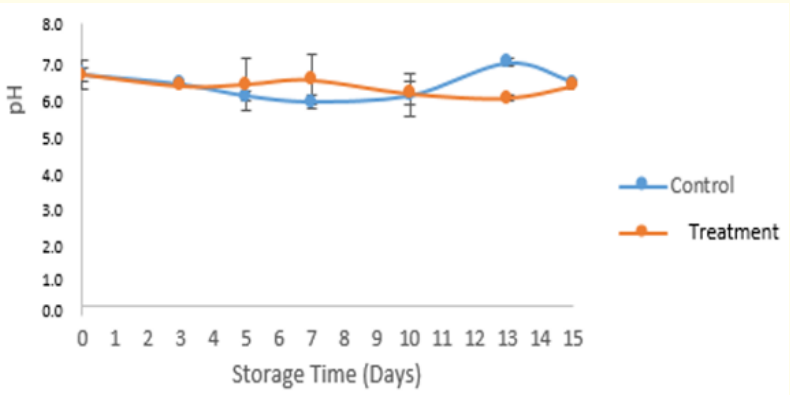

Figure 1: Mean values and standard deviation of the $\mathrm{pH}$ of minimally processed breadfruit depending on the treatment and storage times. 
The analyzes were performed in triplicate. No difference by student's t-test $(\mathrm{p}<0.05)$ between control and treatment.

Water activity average $\left(\mathrm{a}_{\mathrm{w}}\right)$ showed no difference $(\mathrm{p}<0.05)$ between control and treatment during the storage period (Figure 2). The fruit presented high aw content (0.98). $A_{w}$ is directly related to fruit moisture and describes the degree to which water is available to act as a solvent, participating in chemical reactions and microorganism development. It also indicates the intensity of the association between water and non-aqueous constituents and influences the speed of various degradation reactions, such as enzyme-catalyzed reactions [21].

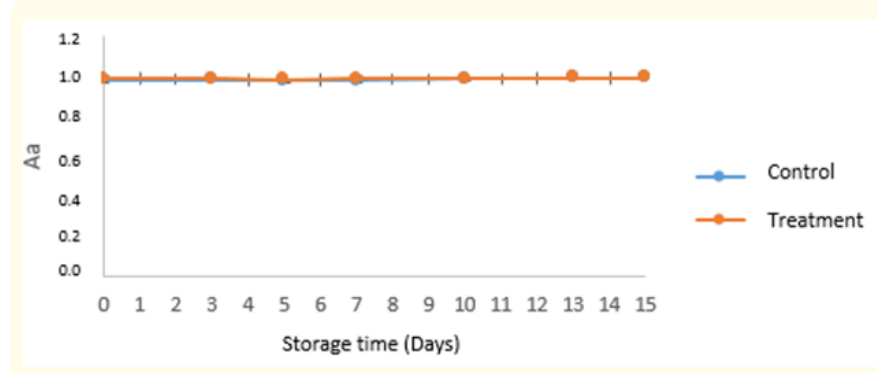

Figure 2: Mean values and standard deviation of the water activity (Aw) of minimally processed breadfruit depending on the treatment and storage time.

The analyzes were performed in triplicate. No difference by student's t-test $(\mathrm{p}<0.05)$ between control and treatment.

Titratable acidity differed $(\mathrm{p}>0.05)$ between control and treatment samples on the 3rd and 10th day of storage (Figure 3). At this point, there was an increase in acidity. These values are higher than those found by Moreira., et al. [22] to physically and chemically characterize Apyrena breadfruit (0.035 mg citric acid.100g-1) and Souza., et al. [23] for fresh breadfruit (0.164 mg of citric acid.100g-1).

The analyzes were performed in triplicate. A significant difference by student's t-test ( $p>0.05$ ) between control and treatment samples on the $3 \mathrm{rd}$ and 10 th days of storage.

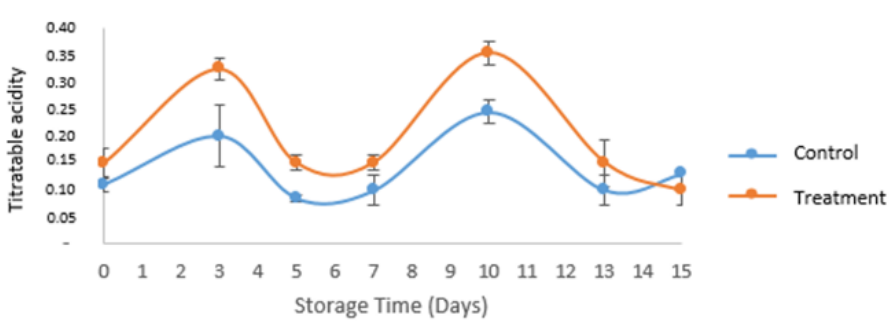

Figure 3: Mean values and standard deviation of titratable acidity (mg citric acid.100g-1) of minimally processed breadfruit depending on the treatment and storage times.

The sugars represent a major part of the soluble solids (SS) and are shown in figure 4 . The SS of breadfruit presented a difference ( $p>0.05$ ), depending on the treatment and storage time. The control sample presented higher values, except on the 13th day. This is explained by the addition of acids used in the treatment, which can be breathable substrates. The increase of SS value up to the 10 th day is justified by fruit natural maturation and the decrease from the 13th day coincides with the increase in the number of microorganisms of total mesophil count (Figure 12), indicating the use of sugars by the microorganisms. Souza., et al. [23], when analyzing soluble solid content in fresh breadfruit, found a lower value (5.6 ${ }^{\circ}$ Brix).

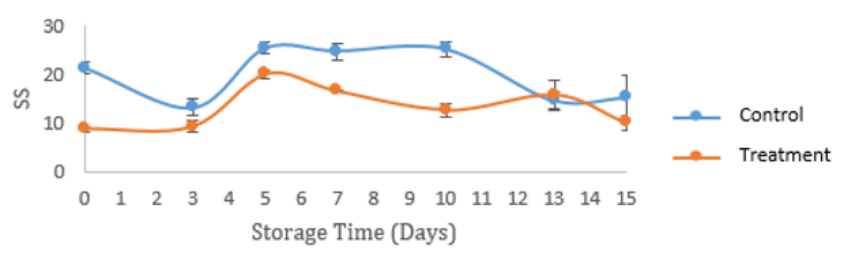

Figure 4: Mean values and standard deviation of Soluble Solids (SS) in ${ }^{\circ}$ Brix of minimally processed breadfruit as a function of treatment and storage.

The analyzes were performed in triplicate. A significant difference by student's t-test $(p>0.05$ ) between control and treatment. 
Mechanical lesions of fruit and vegetable minimal processing lead to biochemical deterioration, such as enzymatic browning. This is caused mainly by the action of the enzyme polyphenol oxidase (PPO) on phenolic compounds present in certain fruits. This is considered the lifespan limiting factor of certain minimally processed fruits. Ascorbic acid as a reducing agent is traditionally applied in combination with other organic acids to prevent enzymatic browning [24].

As breadfruit matures, the firmness of the pulp decreases, making it softer. Values varied between the control and treatment samples, during the storage period, according to figure 5. Treated samples remained firmer than the controls. These results are justified by the addition of calcium chloride solution. Calcium salts are traditionally used to maintain fruit firmness [25]. Guo., et al. [26], when analyzing soluble solids content and pear firmness during ripening, found that storage time generated a significant decrease in firmness after 4 days. According to Brasil and Siddiqui [27], the loss of pulp firmness is an indicator of ripeness and quality that can determine the shelf life of fruit.

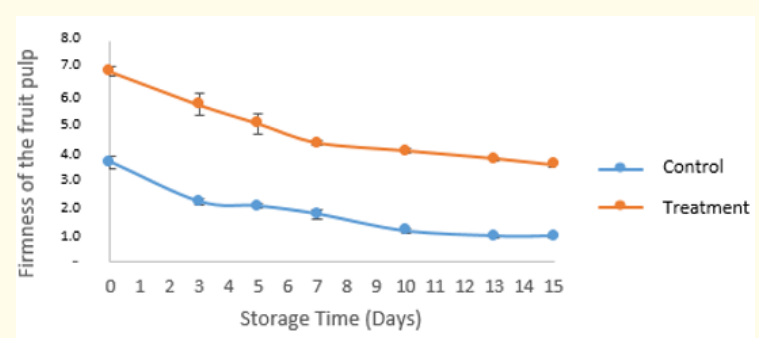

Figure 5: Mean values and standard deviation of firmness of the fruit pulp minimally processed according to the treatment and storage times.

The analyzes were performed in triplicate. A significant difference by student's t-test ( $p>0.05$ ) between control and treatment.

Minimal processing exposes fruit tissue in half, causing a substantial mass loss. Mass loss in minimally processed breadfruit presented in figure 6, was lower in the samples with improvement solution; however, these values did not differ $(p<0.05)$. With the storage passing time, there was an increase in mass loss for all analyzed samples. Chen., et al. [28], studying the effect of ascorbic acid and UV-C combination on the quality of minimally processed apples, did not also find significant differences between the control samples and samples enriched with ascorbic acid.

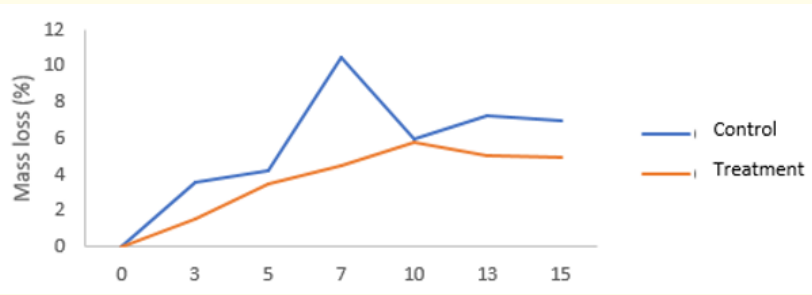

Figure 6: Average values and standard deviation of mass loss of minimally processed breadfruit depending on the treatment and storage times.

The analyzes were performed in triplicate. No difference by student's t-test $(\mathrm{p}<0.05)$ between control and treatment.

As for luminosity $\left(\mathrm{L}^{*}\right)$, presented in figure 7 , there was a significant difference $(\mathrm{p}>0.05)$ between control and treatment samples. Samples with treatment presented a higher index for this parameter, justified by the use of the improvement solution. Reducing agents of this solution are used to avoid browning of processed products, as well as calcium chloride, which action may be due to inhibition of PPO by chloride ions, as well as by diffusion of calcium on tissues, which may have helped to maintain quality, reducing browning. This characteristic was maintained at all times analyzed. These changes in the value of $\mathrm{L}^{*}$ are attributed to enzymatic browning caused by the damage to the fruit tissue and consequent increase of the contact with the PPO enzyme and its substrates.

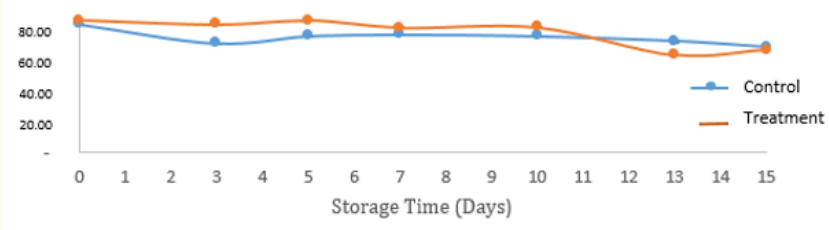

Figure 7: Mean values and standard deviation of $\mathrm{L}^{*}$ of freshly baked breadfruit depending on the treatment and storage times. 
The analyzes were performed in triplicate. Significant difference by student's t-test ( $\mathrm{p}>0.05$ ) between control and treatment samples.

As for $\mathrm{a}^{*}$ coordinate, there was a significant difference between control and treatment samples. Values of $a^{*}$, shown in figure 8, may be used to indicate fruit browning. The results indicated a tendency to brown staining in control samples, characteristic of PPO enzyme action.

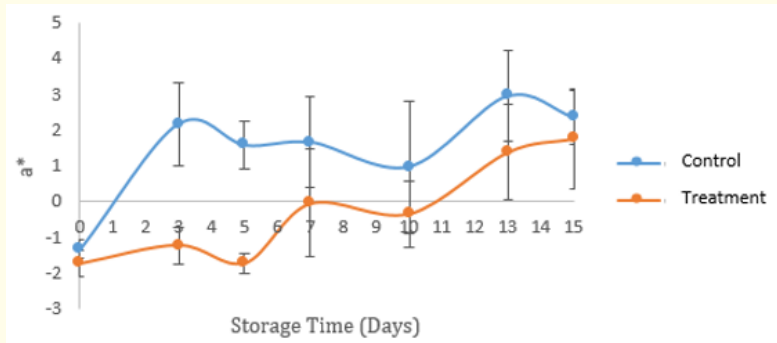

Figure 8: Mean values and standard deviation of a * of minimally processed breadfruit as a function of treatment and storage times.

The analyzes were performed in triplicate. Significant difference by student's t-test ( $p>0.05$ ) between control and treatment samples.

Values of coordinate $b^{*}$ were positive, according to figure 9, which indicates proximity to yellow. This parameter had a significant difference between control and treatment samples, with a higher index in control samples. Degradation reactions may occur during the processing and storage of minimally processed fruits, resulting in browning. These data indicate that the use of acid and calcium chloride improvement solutions showed greater inhibition of PPO enzyme action. Zambrano-Zaragoza., et al. [29] emphasize that the use of chemical additives, such as acidulates (citric acid) and reducing agents (ascorbic acid) have been used in minimally processed fruits and vegetables to control browning.

The analyzes were performed in triplicate. Significant difference by student's t-test ( $p>0.05$ ) between control and treatment samples.

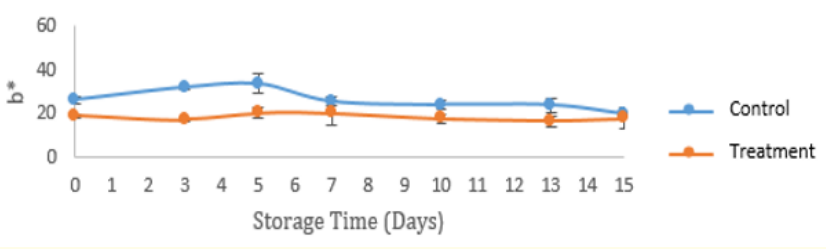

Figure 9: Mean values and standard deviation of $b$ * of freshly baked breadfruit depending on the treatment and storage times.

Roopa., et al. [20], when analyzing the effect of minimum processing and the use of modified atmosphere packaging as a promising way to extend breadfruit lifespan, showed that during the 45 days of storage, there was a significant decrease in the value of $L^{*}$, $\mathrm{a}^{*}$, and $\mathrm{b}^{*}$ over storage time. These results corroborate findings by Chen., et al. [28] when analyzing the effect of citric acid and UV-C use on the quality of minimally processed apples.

Related to the whiteness index, shown in figure 10, it was verified that there was a significant difference between control and treatment samples, during storage. A decrease in this parameter is indicative of browning. Samples with the addition of improvement solution showed higher values for this parameter, except at the end of the evaluated period (13th and 15th days).

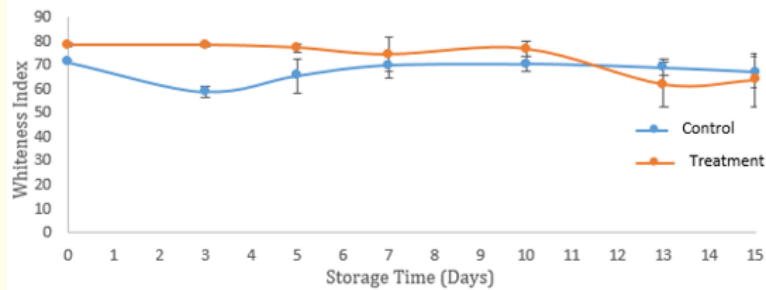

Figure 10: Mean values and standard deviation of the breadfruit whiteness Index minimally processed according to the treatment and storage times.

The analyzes were performed in triplicate. Significant difference by student's t-test ( $p>0.05$ ) between control and treatment samples. 
For darkening index (Figure 11) samples behaved inversely, that is, control samples were darker than those with treatment, justified by the absence of an improvement solution. There is a significant difference between samples over the storage period. This parameter is a factor that limits the lifespan and commercialization of minimally processed fruits.

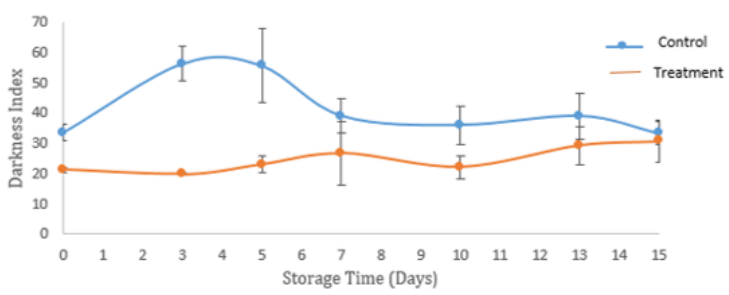

Figure 11: Mean values and standard deviation of the minimally processed breadfruit darkness Index according to the treatment and storage times.

The analyzes were performed in triplicate. Significant difference by student's t-test ( $p>0.05$ ) between control and treatment samples.

These data corroborate those found by Chen., et al. [28], when they evaluated the effect of the addition of citric acid (AC), UV-C and in combination (AC + UV-C) under browning of minimally processed apples, during storage for 15 days at $5^{\circ} \mathrm{C}$. They showed that treatment with citric acid could aggravate the browning of minimally processed apples in a certain period of storage. At the end of the storage, apples treated with citric acid became darker than control samples.

\section{Chemical composition of minimally processed breadfruit}

The chemical composition of food manifests its potential in nutrients, being important data for the food industry. In the literature, information on the approximate composition of minimally processed breadfruit is scarce. Values of moisture, ashes, lipids, proteins, total sugars, carbohydrates, and fibers are presented in table 1.

\begin{tabular}{|c|c|}
\hline Fraction/Source & data \\
\hline Humidity & $57.52 \pm 0.98$ \\
\hline Ashes & $1.23 \pm 0.09$ \\
\hline Lipids & $0.67 \pm 0.04$ \\
\hline Proteins & $1.64 \pm 0.03$ \\
\hline Total Sugars & $3.23 \pm 0.05$ \\
\hline Carbohydrates & 38.94 \\
\hline Fibers & $18.91 \pm 0.02$ \\
\hline
\end{tabular}

Table 1: Chemical composition (g.100 $\mathrm{g}^{-1}$ ) of minimally processed breadfruit.

The breadfruit used in the present study had a mean moisture content similar to that found by Almeida, Feijó, and Marcellini [30] when characterizing green breadfruit biomass. Moisture is a parameter that must be considered because it facilitates fruit deterioration and microbiological development, is related to its stability, quality, and composition.

Ash content analysis provides us with prior information on nutritional value and depends on the food nature and determination method used. Ash content determined in this experiment (Table 1) was higher than that reported in other studies $[1,30]$. This variation can occur naturally influenced by climate, period of the year, and cultivar type of soil.

Lipid contents found are higher (Table 1) than those presented by Turi., et al. [1] and Almeida, Feijó e Marcellini [30]. This variation can be attributed to fruit varieties. This justifies the differences between different sources consulted. The mean value found for proteins was 1.64 g.100g-1; it is close to those found by Almeida, Feijó e Marcellini [30]. Turi., et al. [1] carried out a review of the literature on this fruit and presented mean values of 5.2 g. $100 \mathrm{~g}-1$ for fresh breadfruit proteins. The mean carbohydrate result in breadfruit studied is within the average of the values presented by the other authors cited. In total sugar analysis and fiber fraction, the values found are close to that reported by Almeida, Feijó, and Marcellini [30] when developing and characterizing green breadfruit biomass. 
Total phenolic

All plants produce a remarkable range of secondary metabolites, being phenolic compounds one of the most important metabolites of this group, presenting antioxidant action. The results of total phenol content for aqueous extract of minimally processed breadfruit over a period of 15 days are shown in table 2. The option was water extraction, for most of the phenolic compounds of this fruit presents greater polarity, therefore, they are more watersoluble [30].

\begin{tabular}{|c|c|c|}
\hline Storage time (days) & Control & With treatment \\
\hline 0 & $310.1 \pm 1.05^{\mathrm{Ba}}$ & $350.65 \pm 1.89^{\mathrm{aA}}$ \\
\hline 3 & $280.83 \pm 1.05^{\mathrm{aC}}$ & $250.61 \pm 1.75^{\mathrm{aBC}}$ \\
\hline 5 & $200.76 \pm 2.30^{\mathrm{aD}}$ & $240.11 \pm 2.03^{\mathrm{aC}}$ \\
\hline 7 & $170.67 \pm 1.86^{\mathrm{aE}}$ & $150.69 \pm 2.68^{\mathrm{aD}}$ \\
\hline 10 & $260.52 \pm 2.02^{\mathrm{aBC}}$ & $280.40 \pm 1.43^{\mathrm{aB}}$ \\
\hline 13 & $280.99 \pm 1.36^{\mathrm{aAB}}$ & $240.87 \pm 1.46^{\mathrm{bC}}$ \\
\hline 15 & $200.04 \pm 0.61^{\mathrm{bDE}}$ & $350.60 \pm 1.64^{\mathrm{aA}}$ \\
\hline
\end{tabular}

Table 2: Total phenolic contents in fresh-cut breadfruit (mg GAE.100 g-1 dry sample).

Means followed by the same lowercase letter in the line do not differ significantly from each other by the student's t-test $(\mathrm{p}<$ 0.05). Averages, in the same column, followed by different letters differ statistically according to Tukey's test $(\mathrm{p}<0.05)$

Total phenolic content of control and treatment samples decreased between 9 and $28 \%$ after 3 days of storage. It was verified that there was a significant difference between control and treatment samples, except for the 7th day of storage. The behavior for treated samples did not differ from control on days 0 and 7 , presenting the lowest total phenolic content on the 7 th day of storage (150.69 $\pm 2.68 \mathrm{mg}$ of gallic acid equivalent per $100 \mathrm{~g}$ dry sample) and the highest value on 0 (zero) storage day (350.65 $\pm 1.89 \mathrm{mg}$ of gallic acid equivalent per $100 \mathrm{~g}$ dry sample). However, it presented a significant difference for the other days. This fact can be explained by the addition of citric and ascorbic acids in improvement solution preparation; thus demonstrating the antioxidant action of these acids. The results show that the fresh-cut breadfruit extract promising antioxidant activities have potential bioactivities due to the high content of phenolic compounds.
Jalal., et al. [31] found total phenolic values in breadfruit between $203.17 \pm 7.65$ until $781 \pm 52.97 \mathrm{mg} \mathrm{GAE} / \mathrm{g}$ dry weight of the sample, using methanol and dichloromethane as solvents. Almeida, Feijó, and Marcellini [30] quantified $615.98 \pm 12.44 \mathrm{mg}$ of gallic acid equivalent.100 g-1 of dry sample in green breadfruit aqueous extract.

Variations in the contents of phenolic compounds can be influenced by several factors, such as maturation, species, cultivation practices, geographical origin, growth stage, harvest conditions, and fruit storage process. Methodological peculiarity related to the solvent extractor, whether fresh or dry sample and the phenolic used as a standard for quantification of total phenolic compounds can cooperate for the observed differences.

\section{Evaluation of antioxidant capacity}

Antioxidant activity may depend on several factors, such as oxidation conditions and stages, radical formation and stability, as well as a possible location of antioxidants, and stability in different stages of food processing [32].

For the samples without immersion in improvement solution, EC50 values remained above-treated samples, showing lower values of antioxidant activity (Table 3). Almeida, Feijó, and Marcellini [30] when evaluating the antioxidant capacity of green breadfruit in aqueous extract presented an $85 \%$ reduction of DPPH. after one hour of contact. Jalal., et al. [31], when evaluating pulp, bark, and bark plus breadfruit pulp, using different solvents $(55 \pm 5.89 \mu \mathrm{g}$ / $\mathrm{mL})$ and the control group found significant differences $(\mathrm{p}<0.05)$ between extraction values by part of the $(55 \pm 5.89 \mu \mathrm{g} / \mathrm{mL})$ and control (ascorbic acid, $61 \pm 4.51 \mu \mathrm{g} / \mathrm{mL}$ ). Methanol extract from the part of pulp inhibited the $50 \%$ free radicals of DPPH., being the greater antioxidant activity in the breadfruit pulp.

Means followed by the same lowercase letter in the line do not differ significantly from each other by the student's t-test $(\mathrm{p}<$ 0.05). Averages, in the same column, followed by different letters differ statistically according to Tukey's test $(\mathrm{p}<0.05)$.

The treated sample had the highest antioxidant capacity in the fresh sample on day 0 for the samples with treatment and control. 


\begin{tabular}{|c|c|c|}
\hline Storage time (days) & Control & With treatment \\
\hline 0 & $214.7 \pm 0.5^{\mathrm{aB}}$ & $69.34 \pm 0.05^{\mathrm{bC}}$ \\
\hline 3 & $68.97 \pm 0.03^{\mathrm{aF}}$ & $50.69 \pm 0.07^{\mathrm{bE}}$ \\
\hline 5 & $52.76 \pm 0.09^{\mathrm{aG}}$ & $46.31 \pm 0.09^{\mathrm{bF}}$ \\
\hline 7 & $337.84 \pm 0.01^{\mathrm{aA}}$ & $200.36 \pm 0.04^{\mathrm{bA}}$ \\
\hline 10 & $143.80 \pm 0.02^{\mathrm{aD}}$ & $83.05 \pm 0.06^{\mathrm{bB}}$ \\
\hline 13 & $180.43 \pm 0.03^{\mathrm{aC}}$ & $59.70 \pm 0.07^{\mathrm{bD}}$ \\
\hline 15 & $71.01 \pm 0.08^{\mathrm{aE}}$ & $33.33 \pm 0.04^{\mathrm{bG}}$ \\
\hline
\end{tabular}

\begin{tabular}{|c|c|c|}
\hline Storage time (days) & Control & With treatment \\
\hline 0 & $5.55 \pm 0.04^{\mathrm{bF}}$ & $53.98 \pm 0.04^{\mathrm{aG}}$ \\
\hline 3 & $54.47 \pm 0.04^{\mathrm{aE}}$ & $54.57 \pm 0.05^{\mathrm{aF}}$ \\
\hline 5 & $79.36 \pm 0.04^{\mathrm{bB}}$ & $92.30 \pm 0.20^{\mathrm{aB}}$ \\
\hline 7 & $43.56 \pm 0.04^{\mathrm{bG}}$ & $58.59 \pm 0.10^{\mathrm{aE}}$ \\
\hline 10 & $68.82 \pm 0.05^{\mathrm{bC}}$ & $82.54 \pm 0.03^{\mathrm{aC}}$ \\
\hline 13 & $68.49 \pm 0.13^{\mathrm{bD}}$ & $78.32 \pm 0.09^{\mathrm{aD}}$ \\
\hline 15 & $129.56 \pm 0.07^{\mathrm{bA}}$ & $188.60 \pm 0.06^{\mathrm{aA}}$ \\
\hline
\end{tabular}

Table 3: Antioxidant capacity (EC50 in $\mu \mathrm{g} / \mathrm{mL}$ ) of the minimally processed aqueous fruit extract using the DPPH free radical.

Total Antioxidant Capacity Equivalent to Trolox (TEAC) values found in this study were higher than those obtained by Lan., et al. [33] when analyzing breadfruit antioxidant activity, whose value was 7.2 $\pm 1.6 \mu \mathrm{mol}$ of Trolox/g of the sample (Table 4 ).

Means followed by the same lowercase letter in the line do not differ significantly from each other by the student's t-test $(\mathrm{p}<$ 0.05). Averages, in the same column, followed by different letters

Table 4: Total Antioxidant Capacity Equivalent to Trolox ( $\mu \mathrm{mol}$ Trolox/g sample) by the ABTS method + for minimally processed aqueous fruit extract.

\section{Microbiological analysis}

Like other vegetables, minimally processed fruits have a favorable environment for microbial development. The very composition with high water activity, presence of sugars, and, above all, surface increased by cuts favor microbial development. Microbiological counts of minimally processed and stored breadfruit for 15 days are shown in figure 12. differ statistically according to Tukey's test $(\mathrm{p}<0.05)$.

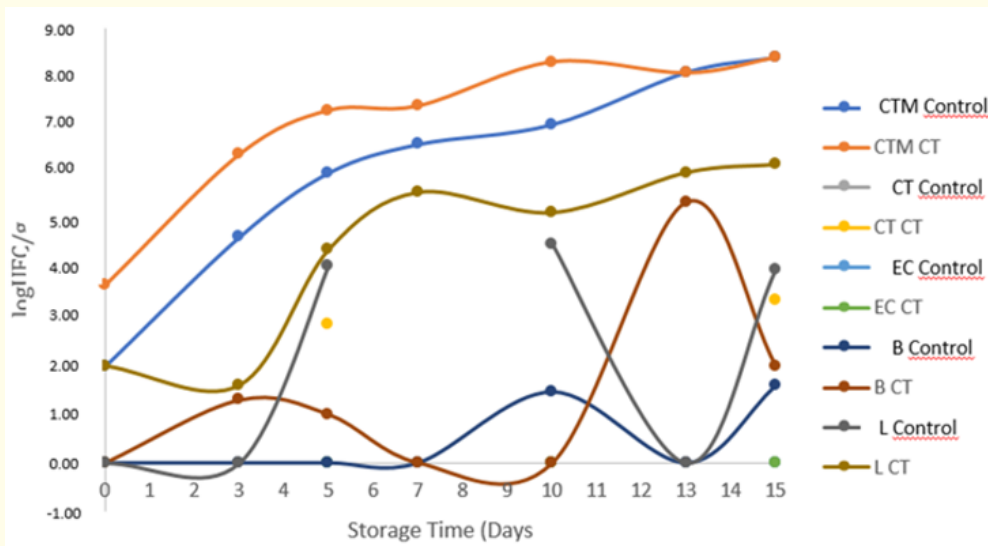

Figure 11: The behavior of the microbiota of breadfruit minimally processed and stored under refrigeration. CTM: Total Mesophyll Count; CT: Total Coliforms; EC: Escherichia Coli; B: Mold and L: Yeast

It is observed that the counts of mesophilic bacteria, coliforms and molds, and yeasts in the control sample and those submitted to treatment increased during storage so that the treatment did not influence product conservation. Insignificant coliform load in control and treatment samples and the slight change during storage indicate that this type of microorganism was not a problem for 
product conservation up to 10 days of storage. Chen., et al. [28], when evaluating the effect of citric acid, UV-C, and citric acid together with UV-C, in minimally processed apples also observed this behavior. They reported that the bacterial count of all treatments increased as the storage time increased, with treatment with citric acid and UV-C presented the lowest rate among all.

Product lifespan definition is determined by sensorial characteristics associated with the results of mesophylls and fungi total count. Roopa., et al. [20], when evaluating minimally processed breadfruit lifespan stored under refrigeration, concluded that the treatment with a conservative solution helped to guarantee product microbiological safety, with no incidence of coliforms or pathogens, having control samples displayed coliforms throughout the storage range.

Fungi behavior (Molds and Yeasts) was determinant for the establishment of product lifespan. Up to the $5^{\text {th }}$ day, it was verified that the microbial load of these microorganisms was below acceptable levels for industrialized plant products, that is, $4 \operatorname{logUFC} / \mathrm{g}$ [34]. Microbiological parameters are not a good indicator to determine the lifespan of this type of minimally processed product, since this will be consumed after thermal treatment.

\section{Conclusion}

This study indicated that immersion in organic acid and calcium chloride solution for 5 minutes was useful to ensure better preservation of physicochemical characteristics of the breadfruit and microbiological quality, with the maintenance of its sensorial aspects.

\section{Bibliography}

1. Turi CE., et al. "Breadfruit (Artocarpus altilis and hybrids): A traditional crop with the potential to prevent hunger and mitigate diabetes in Oceania". Trends in Food Science and Technology 45 (2015): 264-272.

2. Ragone D. "Breadfruit-Artocarpus altilis (Parkinson) Fosberg". Exotic Fruits Reference Guide (2018): 53-60.

3. Huang S., et al. "Cooking loss, texture properties, and color of comminuted beef prepared with breadfruit (Artocarpus altilis) flour". Meat and Muscle Biology 3.1 (2019): 231.
4. Velderrain-Rodríguez GR., et al. "Postharvest Technology of Perishable Horticultural Commodities: Minimal Processing" (2019): 353-374.

5. Azarakhsh N., et al. "Lemongrass essential oil incorporated into alginate- based edible coating for shelf-life extension and quality retention of fresh-cut pineapple". Postharvest Biology Technology 88 (2014): 1-7.

6. Bang IH., et al. "Preservation of mandarins using a microbial decontamination system integrating calcium oxide solution washing, modified atmosphere packaging, and dielectric barrier discharge cold plasma treatment". Food Packaging and Shelf Life 29 (2021): 100682.

7. Ribeiro KCS., et al. "Impact of cold plasma on the techno-functional and sensory properties of whey dairy beverage added with xylooligosaccharide". Food Research International 142 (2021): 110232.

8. Robichaud V., et al. "Effect of $\gamma$-irradiation and food additives on the microbial inactivation of foodborne pathogens in infant formula". LWT 139 (2021): 110547.

9. Traversari S., et al "Combined effect of silicon and non-thermal plasma treatments on yield, mineral content, and nutraceutical proprieties of edible flowers of Begonia cucullata". Plant Physiology and Biochemistry 166 (2021): 1014-1021.

10. Rodríguez GM., et al. "Antioxidant active packaging based on papaya edible films incorporated with Moringa oleifera and ascorbic acid for food preservation". Food Hydrocolloids 103 (2020): 105630.

11. AOAC International. "Official Methods of Analysis (OMA) of AOAC International. USA” (2012).

12. CIE. "Calorimetry Vienna: Commission Internationale deL'Eclairage (2004).

13. Palou E., et al. "Polyphenoloxidase activity and color of blanched and hot hydrostatic pressure treated banana puree". Journal Food Science 64 (1999): 42-45. 
14. Van Soest PJ. "The use of detergents in the analysis of fibrous feeds: II. A rapid method for the determination of fiber and lignin". Journal of the Association of Official Agricultural Chemists 46 (1963): 1-7.

15. Suresh S., et al. "Thermal characteristics, chemical composition and polyphenol contentes of date-pits powder". Journal Food Engineering 119 (2013): 668-679.

16. Brand-williams W., et al. "Use of a method to avaluate antioxidante activity". Lebensmittel-Wissenchaft and Technologie 28 (1995): 25-30.

17. Sanchéz-Moreno C., et al. "A procedure to measure the antiradical efficiency of polyphenols". Journal of the Science of Food and Agriculture 76 (1998): 270-276.

18. Re R., et al. "Antioxidant activity applying an improved abts radical cation decolorization assay". Free Radical Biology and Medicine 26 (1999): 1231-1237.

19. Wu S and Chen J. "Using pullulan-based edible coatings to extend shelf-life of fresh-cut 'Fuji' apples”. International Journal of Biological Macromolecules 55 (2013): 254-257.

20. Roopa N., et al. "Minimal processing and passive modified atmosphere packaging of bread fruit (Artocarpus altilis) sticks for shelf-life extension at refrigerated temperature". Journal of Food Science and Technology 52 (2015): 7479-7485.

21. Rahman MS. "Water Activity and Glass Transition of Foods". Reference Module in Food Sciences (2019): 1-11.

22. Moreira M., et al. "Effects of polysaccharide-based edible coatings enriched with dietary fiber quality attributes of fresh-cut apple". Journal of Food Science and Technology 55 (2015): 795805.

23. Souza DS., et al. "Elaboração de farinha instantânea a partir da polpa de fruta-pão (Artocarpus altilis)". Ciência Rural 42 (2012): 1123-1129.
24. Jiang Y., et al. "Browning: Enzymatic Browning". Encyclopedia of Food and Health (2016): 508-514.

25. Garcia Loredo AB., et al. "Impact of combined ascorbic acid/ $\mathrm{CaCl} 2$, hydrogen peroxide and ultraviolet light treatments on structure, rheological properties and texture of fresh-cut pear (William var.)". Journal of Food Engineering 114 (2013): 164173.

26. Guo Z., et al. "Color compensation and comparison of shortwave near infrared and long wave near infrared spectroscopy for determination of soluble solids content of 'Fuji' apple". Postharvest Biology and Technology Journal 115 (2016): 8190.

27. Brasil IM and Siddiqui M. "Preharvest Modulation of Postharvest Fruit and Vegetable Quality" (2018): 1-40.

28. Chen C., et al. "Effect of citric acid combined with UV-C on the quality of fresh-cut apples". Postharvest Biology and Technology 111 (2016): 126-131.

29. Zambrano-Zaragoza ML., et al. "The effect of nano-coatings with a- tocopherol and xanthan gum on shelf-life and browning index of fresh-cut "Red Delicious" apples". Innovative Food Science and Emerging Technologies 22 (2014): 188-196.

30. Almeida ILGT., et al. "Development, Characterization and Acceptance of Brownie of Green Breadfruit Biomass". Journal of Health Sciences 18 (2016): 144-149.

31. Jalal TK., et al. "Evaluation of antioxidant, total phenol and flavonoid content and antimicrobial activities of Artocarpus altilis (Breadfruit) of underutilized tropical fruit extracts". Applied Biochemistry and Biotechnology 175 (2015): 3231-3243.

32. Pérez-Jiménez J., et al. "Updated methodology to determine antioxidant capacity in plant foods, oils and beverages: Extraction, measurement and expression of results". Food Research International 41 (2008): 274-285. 
33. Lan WC., et al. "Prenylated flavonoids from Artocarpus altilis: Antioxidant activities and inhibitory effects on melanin production". Phytochemistry 89 (2013): 78-88.

34. BRASIL. Resolução RDC n. ${ }^{12}$, de 2 de Janeiro de 2001. Aprova o Regulamento Técnico sobre padrões microbiológicos para alimentos". Órgão emissor: ANVISA - Agência Nacional de Vigilância Sanitária (2001).

\section{Assets from publication with us}

- Prompt Acknowledgement after receiving the article

- Thorough Double blinded peer review

- Rapid Publication

- Issue of Publication Certificate

- High visibility of your Published work

Website: www.actascientific.com/

Submit Article: www.actascientific.com/submission.php

Email us: editor@actascientific.com

Contact us: +919182824667 